ALEKSANDER ŁUPIENKO

https://orcid.org/0000-0002-7568-7455

Instytut Historii im. Tadeusza Manteuffla Polskiej Akademii Nauk

\title{
ŚREDNIOWIECZNE ZABYTKI W NOWOCZESNYM KRAJU. Z DZIEJÓW DZIEWIECTNASTOWIECZNEGO POLSKIEGO DYSKURSU O ARCHITEKTURZE ${ }^{1}$
}

Zarys treści: Artykuł omawia obraz dziedzictwa architektury średniowiecznej w XIX w. (do lat osiemdziesiątych) w polskim dyskursie publicznym. Na podstawie korpusu tekstów z czasopism naukowych oraz książek autor analizuje stosunek do budowli historycznych w dobie rozwijania się idei narodowej i romantyzmu, a potem rosnącej rywalizacji imperiów środkowej Europy na polu kultury. Przedmiotem opisu jest rosnace uznanie dla stylu gotyckiego, z którym wiązano duże nadzieje na przyszłość oraz stan pesymizmu kulturowego lat osiemdziesiątych XIX w.

The content outline: The work discusses the image of the medieval architectural heritage in the Polish public discourse of the nineteenth century. The author uses a corpus of texts published in academic journals and books to analyze the attitudes towards historical buildings in a period marked by intense development of the national cause and Romanticism, and later by the growing competition between the empires of Central Europe in the field of culture. The analysis shows growing esteem for the Gothic style, which was seen as having great potential for the future of architecture, as the well as general pessimistic attitude towards culture prevalent in the $1880 \mathrm{~s}$.

Słowa kluczowe: historia architektury, gotyk, zabytki średniowieczne, dyskurs publiczny w XIX w., Kulturstaat

Keywords: history of architecture, Gothic style, medieval monuments, public discourse in the nineteenth century, Kulturstaat

${ }^{1}$ Niniejszy artykuł prezentuje niektóre wnioski wysnute w trakcie realizacji projektu badań nad architekturą dużych miast na ziemiach polskich od połowy XIX w. do 1914 r. Projekt został sfinansowany ze środków Narodowego Centrum Nauki przyznanych na podstawie decyzji numer DEC-2015/19/D/HS3/03253. 


\section{Uwagi wstępne}

Celem artykułu jest prześledzenie wybranych aspektów stosunku przedstawicieli elity intelektualnej z terenów dawnej Rzeczypospolitej Obojga Narodów (a więc w XIX w. kraju pod zaborami) do zabytków architektury oraz w pewnym stopniu też sztuki w ogóle. Będą to przemyślenia bazujące na analizie korpusu tekstów dotyczących przede wszystkim zabytków architektury, ukazujące dylematy, przed jakimi stawali przedstawiciele tej elity. W prowadzonym wówczas dyskursie dawna architektura, głównie średniowieczna, bywała pretekstem do snucia ogólnych teorii na temat stopnia rozwoju kultury określanej mianem polskiej, oceny przeszłości i wizji przyszłości. Cezurą początkową będzie tu rok 1795, czyli ostateczny upadek państwa polskiego. Omówione zostaną źródła powstałe w czasach Księstwa Warszawskiego, kiedy pojawiły się nadzieje na restytucję państwa polsko-litewskiego, następnie okres „pokongresowy”, czyli czasy istnienia Królestwa Polskiego (do 1831 r. mającego znamiona suwerenności), formalnie niezależnej Rzeczypospolitej Krakowskiej (do 1846 r.), autonomicznego Wielkiego Księstwa Poznańskiego (tracącego znamiona autonomii od lat trzydziestych XIX w.) oraz germanizowanej Galicji (istniejącej formalnie od pierwszego rozbioru). Cezura końcową będą lata osiemdziesiąte XIX w., gdy sytuacja polityczna wyraźnie się zmieniła; sprawa restytucji państwa polskiego zniknęła z agendy wielkiej polityki europejskiej, zabór rosyjski i niemiecki stały się terenem walki z polskościa, Galicja zaś uzyskała dla odmiany status autonomiczny, a jej polskie w charakterze władze mogły prowadzić $\mathrm{w}$ miarę niezależna politykę kulturalna. W ramach tych dat granicznych przemianom ulegała kultura. Nurty oświeceniowego kosmopolityzmu, które odnosiły się także do kultury, traciły od trzeciej dekady XIX w. na znaczeniu, a ich miejsce zajęła kluczowa dla moich wywodów idea romantyczna, podkreślająca różnice między narodami oraz znaczenie dziedzictwa średniowiecza. Ostatnie trzy dekady wieku, po ok. 1863 r., symboliczny moment kryzysu romantyzmu na opisywanych tu terenach, stały się z kolei świadkami rozprzestrzeniania się innego, bardziej trzeźwego i naukowego podejścia do zabytków. Jednak nadany $\mathrm{w}$ okresie romantyzmu kierunek zmian nie uległ zupełnemu przekierowaniu, różnice między narodami i ich kulturami były w dalszym ciagu podkreślane, co prowadziło do stopniowej rywalizacji między nimi, a to w sytuacji braku polskiej państwowości przyniosło nastrój pesymizmu, charakterystyczny moim zdaniem dla ostatnich lat badanego okresu.

Debaty, których przedmiotem stała się w XIX w. także sztuka, prowadzone były przez piszącą po polsku (oraz niekiedy równolegle także 
po francusku, niemiecku i rosyjsku) elitę intelektualna, mieszkająca na terenach dawnej Rzeczypospolitej, a po 1831 r. także na emigracji na zachodzie Europy. Ta „wspólnota komunikacji” rozumiana jest jako ogół ośrodków, w których wydawano interesujace mnie tu pisma, wraz z heterogenicznymi społecznie środowiskami twórców i odbiorców tych pism. Wspólnota ta istniała mimo okresowo wzmagającej się polityki likwidowania pozostałości dawnej Rzeczypospolitej, a potem walki z rodzacym się nowoczesnym polskim ruchem narodowym, podejmowanej przez państwa zaborcze (wpierw głównie austriackie, potem głównie prusko-niemieckie i rosyjskie).

Kluczowy dla moich wywodów jest kontekst upadku państwa w końcu XVIII w. Debaty intelektualne zwykle mają to do siebie, że bazuja $\mathrm{w}$ dużej mierze na pewnych wyobrażeniach, niekoniecznie mających bezpośredni związek z otaczająca rzeczywistością. Kontekst zaborów był tym realnie zaistniałym faktem polityczno-społeczno-gospodarczo-kulturowym, który stał się bodźcem kształtującym opisywany przeze mnie dyskurs, choć oczywiście sama debata nie była pozbawiona także elementów czerpiących bardziej z wyobrażeń jego uczestników niż faktów. Niezależnie od tego, dyskurs ten należy ocenić ze wszech miar pozytywnie, gdyż można widzieć w nim przedłużenie debat prowadzonych przez elity dawnej Rzeczypospolitej, kontynuację dawniejszej tradycji, na którą składały się m.in. spory polityczne i społeczno-religijne od XVI do XVIII w. ${ }^{3} \mathrm{~W}$ niniejszym artykule wzięte będą pod uwagę pisma (książki i artykuły prasowe) powstałe na znajdujacych się pod zaborami ziemiach dawnej Rzeczypospolitej, głównie (choć nie tylko) w miastach. Będą to tereny trzech zaborów (bez tzw. Ziem Zabranych), których życie kulturalne promieniowało z ośrodków takich jak Warszawa, Poznań i Kraków (choć w żadnym wypadku nie ograniczało się do nich). A także ośrodków emigracyjnych, nieobjętych narracją niniejszego artykułu. Ze względu na cel artykułu i jego ograniczone rozmiary skupię się na wybranych, najbardziej mnie interesujących aspektach,

${ }^{2}$ Pojęcia społeczne i polityczne, a także z kręgu sztuki, czyli ważne dla przekazu słowa, używane w tekstach publicystycznych, gazetach i oddzielnie wydanych książkach i broszurach, odnoszą się bezpośrednio do pewnych utartych znaczeń (mówiąc językiem lingwistyki spod znaku Ferdinanda de Saussure'a: element znaczący łączy się ze znaczonym), ale zwykle tylko pośrednio do świata realnego; zob. D. Howarth, Dyskurs, tłum. A. Gąsior-Niemiec, Warszawa 2008, s. 88; por. też na temat tzw. trójkata Ogdena i Richardsa: J. Fiske, Wprowadzenie do badań nad komunikowaniem, tłum. A. Gierczak, Wrocław 1999, s. 63.

${ }^{3}$ Badane obecnie m.in. przez Annę Grześkowiak-Krwawicz, por. np. nowszą pozycję: taż, Dyskurs polityczny Rzeczypospolitej Obojga Narodów: pojęcia i idee, Toruń 2018. 
zostawiajacc na boku istotne tematy, takie jak np. debata na temat stylów narodowych, gdyż mają już one swoją literaturę ${ }^{4}$.

Innym kontekstem omawianych przeze mnie przemian jest rozwój historyzmu rozumianego jako nowoczesna świadomość procesu historycznego ${ }^{5}$. Z tej świadomości brała się z jednej strony potrzeba poznania przeszłości i produkcji wiedzy z tym związanej, z drugiej zaś - potrzeba osadzenia współczesności w historycznym kontekście, „uhistorycznienia” własnej epoki. Tu zaś natrafiano na olbrzymie braki w wiedzy, które skutkowały rozwojem mody na tzw. starożytnictwo, rozumiane tu jako zbieranie wszelkich „artefaktów” dawnego państwa, mających wartość historyczna. Wpierw były one odbierane po prostu jako pamiątki przeszłości narodowej (w znaczeniu, jakie nadało temu określeniu pokolenie księżnej Izabeli Czartoryskiej), potem - bardziej naukowo - jako źródła historyczne. To czasy ostatniego króla polskiego przyniosły pierwsze, jeszcze nieśmiałe w skali próby opracowania syntezy dziejów państwa oraz początki zbierania starożytności. Kontynuacja tych działań pod zaborami wiązała się też z ich dalszym unaukowieniem, co znalazło wczesne urzeczywistnienie w działalności Królewskiego Warszawskiego Towarzystwa Przyjaciół Nauk (KWTPN) od 1800 r., na powstanie którego wydał zgodę król pruski ${ }^{6}$. Tendencja ta uległa wzmocnieniu w czasie rozkwitu romantyzmu, okresie budowania nowoczesnego narodu polskiego. Bogusław Dopart pisał w tym kontekście o pracy pamięci: inwentaryzacji zasobów symbolicznych, odczytywaniu i kultywowaniu narodowej symboliki ${ }^{7}$. Zbieranie wiedzy było jednak procesem powolnym. O tym, jak bardzo była to ograniczona działalność, świadcza losy zbieraczy starożytności z pierwszej połowy XIX w., których praca

${ }^{4} \mathrm{Na}$ ten temat można znaleźć już dużo pozycji, m.in. A.K. Olszewski, Przeglad koncepcji stylu $w$ teorii architektury polskiej przetomu XIX $i$ XX wieku, „Sztuka i Krytyka” 7, 1956, nr 3-4, s. 275-372, 391-394; K. Stefański, Polska architektura sakralna w poszukiwaniu stylu narodowego, Łódź 2002; A. Majdowski, Nurt narodowy $w$ architekturze sakralnej Królestwa Polskiego od drugiej połowy XIX wieku. Wybrane problemy, „Nasza Przeszłość” 64, 1985, s. 5-55 i in.

${ }^{5} \mathrm{Na}$ ten temat m.in. Z. Kuderowicz, Filozofia nowożytnej Europy, Warszawa 1989, s. 30-31; M. Janion, M. Żmigrodzka, Romantyzm i historia, Warszawa 1978, s. 16 nn.; M. Żywczyński, Narodziny i dzieje pojęcia historyzmu (Troeltsch, Meinecke, Croce), „Historyka. Studia Metodologiczne” 1, 1967, s. 51-72.

${ }^{6} \mathrm{O}$ samej instytucji zob. A. Kraushar, Towarzystwo Warszawskie Przyjaciót Nauk 1800-1832. Monografia historyczna osnuta na źródłach archiwalnych, ks. 1: Czasy pruskie: 1800-1807, Kraków 1900; A. Abramowicz, Dzieje zainteresowań starożytniczych w Polsce, cz. 1: Od średniowiecza po czasy saskie $i$ świt oświecenia, Wrocław 1983.

7 B. Dopart, Kultura polskiego romantyzmu: dynamika i pluralizm, w: Środowiska kulturotwórcze czasów oświecenia i romantyzmu, red. B. Dopart, Kraków 2013, s. 93. 
nadal miała znamiona pionierskości. Brak wiedzy i niedobór „artefaktów" nie był bariera, przeciwnie, wzmagał ciekawość i wyostrzał apetyt intelektualny, dlatego zainteresowania archeologiczne (w ówczesnym, bardzo ogólnym rozumieniu tego słowa) przeradzały się w prawdziwy kult przeszłości ${ }^{8}$, implikując także pewną dozę naiwności. W kolejnych dekadach ówczesne debaty kulturalne i działalność względem zabytków dały ostatecznie asumpt do rozwoju bardziej „naukowej”, dojrzalszej i świadomie zorientowanej na rodzimy wydźwięk dyskusji szczegółowej, kiedy to wykształciły się nowoczesne gałęzie nauki (archeologia, historia sztuki, konserwacja zabytków).

\section{Od państwa do narodu}

Zabory były swego rodzaju zimnym prysznicem, szczególnie dla propagatorów oświeceniowego uniwersalizmu kulturowego, idei jedności postępu na świecie i kosmopolityzmu w ogóle, gdyż koncepcje te znalazły się po 1795 r. przynajmniej okresowo w kryzysie. Przeciwnie, oparcie się kultury na idei narodowej, trend zauważalny w Europie na początku XIX w., znajdował na omawianym terytorium szczególne warunki do rozwoju, wsparte dodatkowo zachęcającymi passusami z pism odkrytego na nowo Herdera9 ${ }^{9}$ Odejście od uznawania wyższości państwa do idei nadrzędności narodu było dla elity polskiej znacznie ułatwione, o czym niżej.

Okres Księstwa Warszawskiego i suwerennego, przynajmniej formalnie, Królestwa Polskiego był czasem odradzania się idei lojalności państwowej oraz odczuwania jej potrzeby wśród polskich elit ${ }^{10}$. Lata dwudzieste XIX w., okres zakończenia „flirtu” z liberalizmem cara Aleksandra I, gwaranta konstytucji Królestwa, przyniosły jednak kolejny kryzys. Działalność „policyjna” Mikołaja Nowosilcowa w Wilnie była tego widomym znakiem, przyczyniając się jednocześnie do ukształtowania charakteru nowego prądu intelektualnego - romantyzmu. Wnosił on do

8 Zob. pierwszy rozdział w: A. Zieliński, Poczatek wieku. Przemiany kultury narodowej w latach 1807-1831, Łódź 1973.

9 Zob. D.M. Wilson, The Roots of Medievalism in North-West Europe. National Romanticism, Architecture, Literature, w: Manufacturing Middle Ages. Entangled History of Medievalism in Nineteenth-Century Europe, red. P.J. Geary, G. Klaniczay, Leiden-Boston 2013, s. 113.

${ }^{10}$ Choć także okresem dylematów lojalnościowych; por. J. Czubaty, Zasada „dwóch sumień”. Normy postepowania i granice kompromisu politycznego Polaków w sytuacjach wyboru (1795-1815), Warszawa 2005. 
literatury (i szerzej, do dyskursu) nowe, bardziej holistyczne rozumienie zjawisk kulturowych, przy jednoczesnym akcentowaniu swoistości bytów narodowych. Przypomnijmy, że w swych pismach historiozoficznych Adam Mickiewicz dzielił Europę na poszczególne narody, z jednej strony pozostające w opozycji wobec siebie (narody starsze, dojrzałe i zlaicyzowane, jak angielski, francuski i niemiecki, oraz młodsze, bardziej moralne, jak polski, irlandzki i belgijski), jak i w stosunku do monarchów, oskarżanych o niemoralność i podżeganie narodów do wojen ${ }^{11}$. Dobra ilustracja może tu być także koncepcja literatury u Maurycego Mochnackiego, analizowana przez Stanisława Pieroga. U tego rewolucjonisty i poety jak w soczewce skupiły się te tendencje, wynikające z recepcji ówczesnej filozofii (przede wszystkim Schellinga) oraz z przewartościowania ideałów europejskiego oświecenia pod wpływem lokalnej sytuacji politycznej. Tak jak filozofia oświecenia wyszła poza czysta faktografię (która tak obezwładniała Pierre’a Bayle’a) i wypracowała ideę niezmienności rozumu i stałego postępu ludzkości, tak myśliciele od czasów mało znanego Giambattisty Vica, a na dobra sprawę od Herdera, starali się odżegnywać od kosmopolitycznej i salonowej historii francuskiej $^{12}$. Już taki w swojej istocie klasycysta jak Johann Wolfgang von Goethe był przekonany, że tworząc sztukę dla idealnego społeczeństwa, trzeba brać pod uwagę charakter narodowy w twórczości, co było pokłosiem fascynacji pieśniami ludowymi ${ }^{13}$. Wynikało to ze zmiany paradygmatu $\mathrm{w}$ historiografii, gdzie idea praw rozwojowych ustapiła koncepcji wielości kultur (forsował ją wcześniej Vico) i historii narodowych. W dawnej Polsce łączyło się to ze wspomnianym już szokiem wywołanym zaborami i potrzebą wypracowania modelu kultury bez państwa, co sprawiło, że pojawiła się jeszcze silniejsza niż do tej pory idea absolutyzacji pojęcia sztuki, obecna już np. u Goethego. Teraz sztuka już nie tylko nie naśladowała natury (jak to widzieli wcześni klasycyści), ale była wyrazem sił twórczych genialnej jednostki, która poprzez kontakt ze sztuka sama nabywała zdolności twórczych, jak u lorda Shaftesbury'ego i Edwarda Younga ${ }^{14}$. U Mochnackiego sztuka została

${ }^{11}$ Jak to było w Księgach narodu polskiego i pielgrzymstwa polskiego, passim.

12 E. Cassirer, Filozofia Oświecenia, tłum. T. Zatorski, Warszawa 2010 [oryg. 1932], s. 186-201; I. Berlin, Pod prqd. Eseje z historii idei, red. H. Hardy, tłum. T. Bieroń, Poznań 2002, s. 89; tenże, Pokrzywione drzewo człowieczeństwa, red. H. Hardy, tłum. M. Pietrzak-Merta, M. Tański, Warszawa 2004, s. 191, 197.

13 J.W. Goethe, Literacki sankiulotyzm [1795], w: tenże, Wybór pism estetycznych, wybór, oprac. i wstęp T. Namowicz, Warszawa 1981, s. 116-117; T. Namowicz, Wstęp, w: tamże, s. 27.

14 E. Cassirer, dz. cyt., s. 288-290. 
wyposażona w atrybuty Natury i jej siłę produkcyjna. Dla niego, jak i innych literatów, sztuka umykała prawom logiki, nie dało się jej zrozumieć, a co najwyżej przyjąć jej logikę za własna, co przejął wyraźnie od Schellinga ${ }^{15}$. Jednocześnie jej wytwory nie były jednak uniwersalne, wynikały z różnorodności narodów. Samo pojęcie narodu oraz literatury rozumiane było u Mochnackiego holistycznie: naród rozumiany był jako podmiot zbiorowy, pojmowany jako jedność i całość (jednostkom odmawiano prawa do autonomii ${ }^{16}$ ), a literatura jako jej dusza zbiorowa. Co oczywiste, tak pojęta literatura stała się sama w sobie dowodem na istnienie narodu pod zaborami, a tym samym rola państwa jako warunek istnienia narodu została zdeprecjonowana ${ }^{17}$. Naród istniał tu poprzez kulturę.

Takie właśnie nowe rozumienie kultury i dziedzictwa przebijało i z innych tekstów. Fryderyk Lewestam, pochodzący z Danii krytyk literacki, w filozoficznym artykule o estetyce z $1841 \mathrm{r}$. twierdził we wstępie do swych wywodów, że „[w] dziełach sztuki spoczywaią wyobrażenia narodów; ich mądrość i wiara bez tego tajemniczego klucza nie razby zaginęły"18. Sztuka stoi tu więc na straży odrębności narodu wobec groźby utraty tożsamości narodowej, czyli tej wspomnianej wyżej wewnętrznej „mądrości”, w kontekście - przypomnijmy - zaawansowanych już działań zmierzających do marginalizacji kultury polskiej we wszystkich zaborach, szczególnie w Królestwie Kongresowym i Galicji. W jednym z najważniejszych wczesnych dzieł z dziedziny estetyki polskiej, kamieniu milowym tej nauki, koncepcja narodowości sztuki także była obecna. Karol Libelt, kontynuator myśli Hegla i autor Estetyki czyli umnictwa pięknego, stawiał sztukę na równi z dwoma innymi dziedzinami objawiania się transcendentnego ducha w człowieku - religia i filozofia. Miała ona pośredniczyć w rozwoju ludzkości od religii do filozofii: „gdzie na horyzoncie narodu jakiego pojawi się poezya i sztuka, nie z naśladownictwa, ale z pierwotwórczych, świeżych, jędrnych, czysto narodowych pojęć wydobyta, tam wschodzi jutrzenka jego w różanym blasku poranku, tam niebawem i rodzima zejdzie filozofia” ${ }^{19}$. Wydobywa się z „narodowych pojęć”, gdyż - dodajmy - naród jest tu naturalnym, zesłanym od Boga

15 R. Panasiuk, Schelling, Warszawa 1988, s. 76-81.

16 Jak to było u Mickiewicza, w odróżnieniu np. od filozofii Trentowskiego, zob.

A. Walicki, Filozofia polskiego romantyzmu, Kraków 2009, s. 324.

${ }_{17}$ S. Pieróg, Maurycy Mochnacki. Studium romantycznej świadomości, Warszawa 1982, s. 276.

${ }^{18}$ F.H. Lewestam, Wyjatki z estetyki, „Biblioteka Warszawska” 3, 1841, s. 81-100, tu s. 85.

${ }_{19}$ K. Libelt, Estetyka czyli Umnictwo Piękne. Część ogólna, Petersburg 1854, s. 30-31 (wyd. 1: Poznań 1849). 
typem wspólnoty ludzkiej. Narodowość nadaje charakter wszystkim dziełom i poczynaniom człowieka, co prowadziło Libelta do ciekawego porównania. Wszystkie wytwory człowieka porównane zostały do wielkiego oceanu, który, mimo że woda w nim jest przezroczysta, ma jednak barwę zależną od rodzaju dna, które się pod nim znajduje. „Usposobienie narodu, który z siebie wysnuł sztuki piękne, nada im pewną narodową barwę, wyciśnie niejako na nich pieczęć ducha swego, dając znać, że są jego własnościa”. Po czym autor dodawał, że „[a]rchitektura najwydatniej pokazuje na sobie cechy narodowego ducha" ${ }^{20}$. Grunt, nomen omen, pod narodowe pojmowanie sztuki został położony.

W dylematach ideowych polskich elit pod zaborami kategoria narodu ulegała okresowemu słabnięciu, tracąc swą centralną rolę w okresie triumfu w wielu kręgach filozofii pozytywistycznej. Według hołdujących idei postępu myślicieli państwa jako nadrzędnej jednostki politycznej nie można było ignorować. Szczególnie w Galicji po uzyskaniu przez nią autonomii pod polskimi rządami konserwatyści pokroju Michała Bobrzyńskiego podkreślać zaczęli wagę sprawnej i silnej państwowości. Za to pozytywiści warszawscy, żyjący w rządzonym silną ręką zaborze rosyjskim, gdzie przejawy polskości były w najlepszym razie zaledwie tolerowane, propagowali raczej ideę liberalizmu i leseferyzmu, a nie etatyzmu, a termin „naród” zastępowany był często pojęciem „społeczeństwo" 21 . Ważnym czynnikiem było również unaukowienie badań nad historia architektury, sprawiające, że ideałem stało się pisanie bardziej obiektywne, bez wikłania się w spory narodowe, co jednak w praktyce było trudne do realizacji pod zaborami, o czym niżej. Romantyczny typ myślenia długo pozostawał żywy. W artykule Kazimierza Kaszewskiego, tłumacza i krytyka literackiego ${ }^{22}$ z końca lat siedemdziesiątych, autor, omawiając cele sztuki i jej społeczną użyteczność, uznał, że najważniejszym kryterium jest to, czy dzieło sztuki wyobraża psychiczna całość społeczeństwa, w którym powstaje. Za czynniki kształtujące sztukę przyjął środowisko oraz „psychologię plemienną i narodowa” na danym terenie. Sztuka taka miała dążyć ku „jednemu punktowi, od którego promienieje jedność fizyognomii, nadająca utworom pewne rysy familijne" 23 . Jednym słowem nadal warunki

20 Tamże, s. 38.

${ }^{21} \mathrm{Na}$ ten temat zob. G. Markiewicz, Między państwem obcym a idea państwa własnego. Świadomość państwowa polskich elit intelektualnych w latach 1864-1914, Łódź 2010.

22 A. Biernacki, Kaszewski Kazimierz, w: PSB, t. 12, 1966-1967, s. 201-203.

${ }^{23}$ K. Kaszewski, W sprawie pożytku i piękna, „Biblioteka Warszawska” 3, 1877, s. $1-25$, tu s. $16-17$. 
narodowe implikowały powstawanie narodowej sztuki. Nie znaczyło to, że sztuka nie powinna być różnorodna w formach, ale dla estetyków i krytyków miała jeden podstawowy, wspólny, narodowy mianownik, który nadawał jej wyraźne piętno. Co ważne, tego typu przemyślenia ułatwiały intelektualne radzenie sobie z rzeczywistością zaborowa, gdyż podkreślały autonomię kategorii narodowości w dziedzinie kultury.

\section{„Kariera” gotyku w XIX w.}

Architektura w oczach teoretyków zawsze łączyła w sobie użyteczność i piękno, a w interesującym nas okresie coraz częściej była rozpatrywana jako jedna ze sztuk pięknych, stając się domena estetyki jako nauki. Dzieła sztuki i architektury były rozpatrywane w kategorii ziemskiej (potem też pozaziemskiej) transcendencji, szczególnie zabytki pozostawione przez starożytnych Greków. Uznanie dla obiektów dawnej architektury zaczęło się łączyć z kategorią wzniosłości, wynikało bowiem z tego, że obiekty te miały uwznioślać duszę, a inspiracją ku temu były pisma Edmunda Burke'a ${ }^{24}$. Przejście od kategorii piękna i przyjemności do koncepcji wzniosłości, rozwijanej od czasów lorda Shaftesbury'ego ${ }^{25}$, utorowało droge „heterodoksyjnym” opiniom na temat sztuki czasów średniowiecza. Burke, wychodząc od dominujacych na Wyspach Brytyjskich zasad empirycznych oraz uznawanych za fundamentalne dla ludzkości badań przyrodniczych, uznał, że doznania piękna wynikaja ze źródeł biologicznych. Przyporządkowując wzniosłość popędowi do samozachowania, uznał, że objawia się ona w tym, co niebezpieczne ${ }^{26}$. Wpływ Burke'a widać u Goethego, np. w jego recenzji z pracy Johanna Georga Sulzera $O$ pochodzeniu sztuk pięknych z 1772 r., gdzie podkreślał, że szalejące burze (motyw wzięty wprost z Burke'a), potopy, wybuchy wulkanów i śmierć są także dziełami natury i nie można ich ignorować $\mathrm{w}$ teoriach estetycznych ${ }^{27}$. Wzniosłość okazała się idealna kategoria do opisu budowli religijnych, gdzie miała konotować uczucie podziwu dla ogromu oraz nieskończoności Boga, co trudno byłoby uznać za kontemplację czegoś przyjemnego lub zmysłowo estetycznego, choć u lorda Shaftesbury'ego, czyli na przełomie XVII i XVIII w., kontemplacja ogromu nieskończoności miała dostarczać człowiekowi uczucia

${ }^{24}$ D.M. Wilson, dz. cyt., s. 111.

${ }_{25}$ Zob. A. Grzeliński, Angielski spór o istotę piękna. Koncepcje estetyczne Shaftesbury'ego i Burke’a, Toruń 2001, s. 89-99.

26 Tamże, s. 34.

${ }^{27}$ J.W. Goethe, dz. cyt., s. 85. 
przyjemności ${ }^{28}$. Takie podejście (nazwijmy je idealistycznym) do architektury było zauważalne przez cały wiek XIX. Przykładowo w rozprawie o malarstwie astronoma, matematyka i artysty amatora Józefa Łęskiego $^{29}$, opublikowanej przez Towarzystwo Naukowe Krakowskie w 1817 r., to oddziaływanie nazwane zostało siła moralna, w szerszym, dziewiętnastowiecznym znaczeniu moralności, nieograniczającym się do religii. Siła moralna miała być jedną z cech dzieł sztuki, obok piękności i stosowności, cecha, która czyniła z estetycznego obiektu wytwór sztuk pięknych ${ }^{30}$. Wymóg „wznoszenia duszy” powtarzał się w kolejnych tekstach teoretycznych, stając się rodzajem utartego motywu.

Architektura była szczególnym przykładem sztuk pięknych także ze względu na swą skalę i trwałość. Tu dotykamy już bliskiej naszym rozważaniom kwestii powiązania architektury i kultury narodowej. Myśliciele początku XIX w. byli wrażliwi głównie na piękno antyczne, stąd nie dziwi, że wskazywali na skalę i efekt wywierany przez dawne budowle jako materialne pozostałości ludzkiej cywilizacji. Według Ignacego Mieroszewskiego, malarza, rzeźbiarza i poety krakowskiego, architektura zajmowała wiodące miejsce w dziejach wytworów ludzkich, ze względów praktycznych była pierwsza sztuką opanowana przez człowieka, a ruiny Rzymu uznane przede wszystkim za materialny ślad dawnej potęgi ${ }^{31}$. Tego typu myślenie dawało asumpt do długich dyskusji dotyczacych pamiątek po innej dawnej potędze, Rzeczypospolitej, której pogrobowcami czuli się przedstawiciele omawianej elity.

Wracając do wątku religijnego, okres zaborów zbiegł się w czasie z pierwszymi symptomami doceniania sztuki średniowiecza, przede wszystkim gotyku, wpierw na Wyspach Brytyjskich, a potem także na kontynencie. Wpływ miał na to dodatkowo krótki skądinąd okres sprzyjający idei chrześcijańskiej, który został wytworzony przez publikacje z okresu porewolucyjnego odrodzenia katolickiego, szczególnie przez przełomową książkę François-René de Chateaubrianda Geniusz chrześcijaństwa z 1802 r. oraz mistyczne pisarstwo Augustusa Welby'ego Northmore'a Pugina ${ }^{32}$. Skupię się w tym miejscu na tym pierwszym.

28 A. Grzeliński, dz. cyt., s. 95.

${ }^{29}$ K. Mrozowska, Łęski Józef Franciszek Stanisław, w: PSB, t. 18, 1973, s. 358-360.

30 J. Łęski, Rozprawa o piękności w sztukach a szczególniey w malarstwie, „Rocznik Towarzystwa Naukowego Krakowskiego" 1, 1817, s. 259-319, tu s. 270.

${ }^{31}$ I. Mieroszewski, Rozprawa o malarstwie, „Rocznik Towarzystwa Naukowego Krakowskiego" 3, 1818, s. 199-245, tu s. 213-214. Widać tu być może wpływ przemyśleń francuskiego filozofa Constantina Volneya o przemijaniu cywilizacji; por. Z. Kuderowicz, dz. cyt., s. 439.

${ }^{32}$ Por. K. Clark, The Gothic Revival. An Essay on the History of Taste, London 1962 [oryg. 1928], s. 122-149. 
Chateaubriand potraktował religię chrześcijańską (można uściślić: katolicyzm) w kategoriach niemal czysto estetycznych, opowiadając, jak pięknie rozwijają się główne idee religijne w poezji, malarstwie, rzeźbie i architekturze ${ }^{33}$. Wychowany w kulturze klasycystycznej i zwolennik monarchii, torował drogę dla uznaniu gotyku. Choć pisząc o architekturze, dawał przykłady piękna z czasów renesansu i baroku (kopuła jako ucieleśnienie idei chrześcijańskiej), zwrócił też uwagę na walory dawnych dzwonnic oraz gotyk, którego źródła upatrywał w naśladowaniu form natury (lasu). Nie uznawał jednak form gotyckich za piękne per se (,,barbarzyńskie proporcje”). To, co w nich było szczególnego to ich dawny wiek: przybytki kultu Boga miały „tonąć w nocy dziejów”" To dzieło i inne sprawiły, że do głównego nurtu dyskursu elit przeniknęła myśl obrońców budownictwa średniowiecznego. Łączyć to trzeba także z impulsami literackimi rodzącego się romantyzmu, w tym kultem zabytków piśmiennictwa średniowiecznego, nie tylko zresztą chrześcijańskiego. Nie od rzeczy będzie wspomnieć wcześniejszy i bardzo znany tekst klasycysty Goethego z 1772 r., który w młodzieńczym uniesieniu na widok katedry w Strasburgu dowodził, że tysiące elementów tworzących katedrę nie jest chaosem, ale tworzą harmonię, jednostajność zaś przypisał długim rzędom kolumn, charakterystycznych dla antyku, a przy okazji sa przykładem architektury narodowej, niemieckiej ${ }^{35}$. Ten klimat wpłynał na badane przeze mnie teksty poświęcone sztuce. Wskazać tu można ambitny tekst referatu z 1832 r. jezuity ks. Franciszka K. Stachowskiego, duchownego związanego z biskupem Janem Pawłem Woroniczem i filologa ${ }^{36}$, opublikowany w „Roczniku Towarzystwa Naukowego z Uniwersytetem Krakowskim połaczonego” w Krakowie. Celem wykładu było udowodnienie, że sztuka chrześcijańska była ważnym rozdziałem historii sztuki, a stojący u jej podstaw „duch twórczy chrystianizmu" stworzył kościoły, które przemawiały do serca dużo bardziej niż „nieme, ciężkie i poziome” świątynie starożytne ${ }^{37}$. W kościołach tych upatrywał autor wyższego piękna, alternatywnego

${ }^{33}$ Por. F.-R. de Chateaubriand, Geniusz chrześcijaństwa, wybór, tłum. i wstęp A. Loba, Warszawa 2004.

${ }_{34}$ Tamże, s. 243-244, 249-250.

35 J.W. Goethe, O niemieckiej architekturze, w: tenże, Wybór pism estetycznych..., s. 73-74; por. W.D. Robson-Scott, The Literary Background of the Gothic Revival in Germany. A Chapter in the History of Taste, Oxford 1965, s. 84-88.

36 W. Kolak, Stachowski Franciszek Ksawery, w: PSB, t. 41, 2002, s. 338-340.

${ }^{37} \mathrm{Ks}$. K. Stachowski, O wptywie Religii Chrześcijańskiej na wzrost i postepy sztuk pięknych, „Rocznik Towarzystwa Naukowego Krakowskiego” 2 (17), 1843, s. 143-154, tu s. 148. 
wobec antycznego, a „umocowanego" w perspektywie transcendencji: „Religia bowiem unosi myśl człowieka w krainę umysłowego świata, stawi go w bliskiem zetknięciu się z Twórca, usuwa przed nim zasłonę kryjąca Jego wielkość, daje mu poznać cuda dzieł Jego i sposobi umysł do przyjęcia wrażeń wyższego rzędu do pomysłów wzniosłych i szczytnych" ${ }^{38}$. Autor podją się w tym tekście nie tyle obrony zasad wiary, ile także związanej z chrześcijaństwem architektury kościelnej, co ma tu duże znaczenie.

Istotnym impulsem były teorie drugiego ważnego estetyka pierwszej połowy XIX w., romantycznego interpretatora Hegla, Józefa Kremera. W swym słynnym pierwszym tomie Listów z Krakowa z 1843 r. wsparł on ideę pełnej autonomii sztuki, dowodząc, że prawdziwa sztuka nie ma i w istocie nie może mieć utylitarnych celów, jest celem samym $\mathrm{w}$ sobie $^{39}$. Co więcej, inaczej niż klasycyści, podkreślał, że jej zadaniem nie było naśladowanie Natury, gdyż ją w istocie przerastała, była emanacją Ducha w człowieku, łączącą ludzką skończoność z Boską nieskończonością ${ }^{40}$. Zwrócił przy tym uwagę, że czasem tę nieskończoność wyrażają dzieła architektury. Ale, podobnie jak piszaccy po nim inni teoretycy sztuki epoki romantyzmu, tego typu wzniosłe, transcendentne cechy łączył wyłącznie ze średniowieczną architektura kościelną. Część listu IX była w istocie peanem na cześć katedr katolickich ${ }^{41}$. Aby wyjaśnić, jak działa geniusz twórczości w człowieku, wprowadził Kremer w drugim tomie Listów, wydanym w 1855 r., pojęcie fantazji, które definiował jako ,iskrę bożą" ${ }^{2}$.

Również u piszącego w tym samym czasie Edwarda Dembowskiego spotykamy w teoriach dotyczących sztuki kategorię twórczości jako jedności myśli i uczucia. Uczucie oraz waga (romantycznego) czynu były tu ważnymi kategoriami, piękno zaś mniej ważne niż wzniosłośćc ${ }^{43}$, co łączyło się z wpływem Hegla, „przefiltrowanego” przez myśl Augusta Cieszkowskiego, i świadczyło o aktywistycznym podejściu także w filozofii sztuki. Libelt zbudował swoja teorię na nieco innych podstawach. Tutaj też mamy do czynienia z Boska proweniencją natchnienia oraz idea sztuki jako celu samego w sobie, ale najważniejszą kategorią

38 Tamże, s. 151.

${ }^{39}$ J. Kremer, Listy $z$ Krakowa, t. 1, Wilno 1855 (wyd. 1: Kraków 1843), List II, s. $25 \mathrm{nn}$.

${ }^{40}$ Tamże, List IV, s. 62, List VII, s. 195.

${ }^{41}$ Tamże, List VII, s. 200, List IX, s. 282-284.

${ }^{42}$ J. Kremer, Listy $z$ Krakowa, t. 2, wyd. 1, Wilno 1855, List XI, s. 12.

${ }^{43}$ L. Wiśniewska-Rutkowska, Zaczarowany rewolucja. Rzecz o Edwardzie Dembowskim, Toruń 2018, s. 121, 148-149. 
była wyobraźnia, znana z rozważań estetycznych doby oświecenia, np. z traktatu Jeana-Baptiste'a Dubos (1719), ale tu inaczej pojmowana ${ }^{4}$. Wyobraźnia była równie ważna, ale i autonomiczna „potęga” człowieka jak serce i rozum ${ }^{45}$, odpowiedzialna za twórczość. „Sztuki piękne przedstawiaja świat zupełnie inny, osobny, niżeli jest świat rzeczywisty, a w tym świecie zamiast tworów Stwórcy Boga, widzimy twory stwórcy człowieka, i w nich objawienie się do zmysłów nieskończonego ducha, w całym rozwoju narodów i wieków" ${ }^{46}$. Już nie tylko twory sztuki, ale twórczość jako ludzka umiejętność była tu objawieniem ducha Boga na ziemi, stą już było blisko do uznania architektury za sztukę ponadziemska, „mieszkanie dla idealności” ${ }^{47}$. Architektura gotycka została uznana za znak największego uwznioślenia ducha ludzkiego. „Widzimy to rozpiętrzanie, rozmaganie się ducha w architekturze gotyckiej, jakby chciał rozsadzić formy, co go ściskaja, i strzelić w nieskończoność, aż ku niebu" ${ }^{48}$ - pisał Libelt. Jednocześnie był świadomy różnicy między dawnym podejściem do sztuki religijnej i tym dziewiętnastowiecznym. I choć obie epoki estetyczne nazywał „romantyzmem”, to tylko ten dawny miał kierować się niewzruszona wiara: „Romantyzm średniowieczny rozbudzony był wielkiemi ideami wiary, nadziei i miłości. Brał pożywne soki z głębokich natchnień religijnych, dusza gorzała żywą wiara, cudotwórczość zlewała się z kształtami fantazyi i sprowadzała Boga i jego potęgi na ziemię, roztwierała przytem świat pozaziemski z całem bogactwem form niebios i piekieł" 49 .

W związku z tym, co warto odnotować, nie przyznawał idei „dorabiania" dawnych dzieł miana prawdziwej sztuki, która to sztuka miała być autonomiczna i w pełni twórczo swobodna ${ }^{50}$, co w kontekście odnawiania dawnych kościołów mogło być poczytane za wsparcie twórczego podejścia do restauracji zabytków.

Tego typu język wprowadzony do dyskursu architektonicznego pojawiał się odtą wielokrotnie, czego przykładem jest np. opis architekta Filipa Pokutyńskiego z 1869 r.: „I prawem idei wzlatuja pod niebiosy

${ }^{44}$ E. Cassirer, dz. cyt., s. 276.

${ }^{45}$ K. Libelt, dz. cyt., s. 21, 24.

46 Tamże, s. 88.

${ }_{47}$ Tego typu podejście wcale nie zanikło wraz z pozytywizmem, a do epigonów takiego myślenia zaliczał się m.in. wpływowy estetyk Henryk Struve; por. tenże, Sztuka i społeczeństwo, wykład publiczny z 1903 r., w: tenże, Wybór pism estetycznych, wprow., wybór i oprac. J. Sztachelska, Kraków 2010, s. 74.

${ }^{48}$ K. Libelt, dz. cyt., s. 174.

49 Tamże, s. 328.

50 Tamże, s. 168. 
ciężkie głazy kamienne. Materya poddaje się duchowi, który je dźwiga skrzydły swojemi, gotycyzm dzierga lotne koronki kamienne, i gwałtem logiki konstrukcyjnej (opartej li na wysokiej technice) ciska ku stropom niebios; wieże swych katedr kapie w nadzwyczajnych wysokościach - obie pochyla ku sobie, zlewając w jednę bez końca całość, której szczyt ginie w przestrzeniach nieba, jak idea religii, której to kresem tamten świat przyszły, pełen tajemnic" ${ }^{21}$. A także dużo późniejsza broszura proboszcza nowo wzniesionego warszawskiego kościoła św. Barbary na Koszykach, w stylu średniowiecznym (tu: neoromańskim). Czytamy w niej, że gotyk „to okręt, w którym duch ludzki, zachwycony pieśnią o niebie, chciał ulecieć do nieba" ${ }^{52}$. Cytaty te ilustruja zmianę, jaka się dokonywała w stosunku do dziedzictwa gotyku i średniowiecza w ogóle, a także była symptomem tworzenia się nowoczesnego narodu, zgodnie z przyjętymi przez badaczy zagadnienia prawidłowościami. Tęsknota za przeszłościa była ważnym „paliwem” napędzającym machinę kształtowania ideologii narodowej, a pochwała dawnych wieków budownictwa (i kultury w ogólności), choć czasem tylko implicite wiązana przez autorów z przeszłościa państwa polskiego, nie była niczym innym jak próbą kreowania dyskursu „odwieczności” narodu i szukaniem kontynuacji w historii ${ }^{53}$.

\section{Unarodowienie sztuki i kwestie stylowe}

Równolegle jednak dyskurs estetyczny ulegał stopniowemu „unarodowieniu”, przy czym należy pamiętać, że sam termin „naród” był nieco inaczej rozumiany przez kolejne pokolenia myślicieli. Cofając się w przeszłość, należy zacząć od konstatacji, że region i okolica, w jakiej miała powstać budowla była istotna w teorii architektonicznej od starożytności, by wymienić jedynego znanego teoretyka antycznego, Witruwiusza, który zwracał uwagę na kontekst geograficzno-geologiczny wytyczania miast. Na naszym gruncie kontekst ten, nazywany „niebem polskim”, także miał duże znaczenie. Klasycyzm w architekturze przyniósł idee

${ }^{51}$ F. Pokutyński, Jak zapatrywać się należy na kierunek dzisiejszej architektury. Zarys osnuty na podstawie Historyi sztuki, „Rocznik Towarzystwa Naukowego Krakowskiego" 38, 1869, s. 258-275, tu s. 264-265.

${ }^{52}$ W. Witkowski, Nowy kościót w parafii św. Barbary w Warszawie, Warszawa 1885, s. 2.

${ }_{53}$ A.D. Smith, Etniczne źródła narodów, tłum. M. Głowacka-Grajper, Kraków 2009, s. 19, 83, 280-282; J. Assmann, Pamięć kulturowa: pismo, zapamiętywanie $i$ polityczna tożsamość $w$ cywilizacjach starożytnych, tłum. A. Kryczyńska-Pham, wstęp i red. R. Traba, Warszawa 2008, s. 94-95, 147. 
uniwersalistyczne, a źródła piękna upatrywał jedynie w „guście starożytnych", we wspólnej europejskiej spuściźnie. Jeśli jednak przyjrzymy się przykładowo wydanej w 1812 r. (a wcześniej jako artykuł w „Roczniku Towarzystwa Przyjaciół Nauk") Rozprawie o guście Piotra Aignera, wybitnego warszawskiego architekta klasycysty z początku XIX w., który w swym traktacie propagował estetykę klasycystyczna, widać odniesienia do „ducha narodowego” ${ }^{4}$, który kształtuje dzieła architektoniczne. Na marginesie można dodać, że zwrócił on tam uwagę na wpływ architektury na człowieka, dając przykład Aten, których budowle kształtowały dobry gust mieszkańców ${ }^{55}$. Kontekstualizacja dzieł sztuki była krótko omówiona tė̇ przez wspomnianego już Józefa Łęskiego ${ }^{56}$.

Istotny był tu też wkład reformatora oświaty i filozofa Hugona Kołłątaja, który odchodząc od oświeceniowego prawa natury, doszedł do przekonania, że historia nie jest ucieleśnieniem odwiecznych praw rozumowych (jak w teoriach Woltera i Condorceta), ale w swej istocie przypadkowa i dramatyczna „przygoda” ludzkości. Pretekstem do takiego ujęcia dziejów był słynny argument potopu, który miał zniszczyć dawna, harmonijną kulturę ludzką i wprowadzić do świata nieład i tyranię. Skoro zaś nie można było wyprowadzić praw historii droga rozumowa, trzeba było studiować historię poszczególnych narodów, jak to wyraził Kołłątaj w znanym liście do księgarza Jana Maja w 1802 r. ${ }^{57}$ W ten sposób kontekst narodu został tu szczególnie uwypuklony. Jak u Giambattisty Vica, uznanie zdobyło przekonanie, że naród może poznać sam siebie poprzez studiowanie historii ${ }^{58}$. Element patriotyzmu był tu moim zdaniem silniejszy niż naukowy. Dla naszego tematu istotne jest, że historia ta miała obejmować także szeroko pojmowaną kulturę, badając różne jej wytwory oraz wszystkich jej wytwórców, czyli także lud. W swym Kursie dwuletnim Historyi $i$ Jeografii Powszechnej dla szkoły w Krzemieńcu Kołłątaj wyjaśnił, że przedmiotem badania historii powinny być m.in.: religia, umiejętności, nauki, sztuki i wynalazki ${ }^{59}$.

${ }^{54}$ P. Aigner, Rozprawa o guście $w$ ogólności, a w szczególności w Architekturze, Warszawa 1812, s. 23.

55 Tamże, s. 18.

56 J. Łęski, dz. cyt., s. 279.

${ }^{57}$ X. Hugona Kottataja korespondencja listowna $z$ Tadeuszem Czackim, t. 1, wyd. F. Kojsiewicz, Kraków 1844, s. 12-30. O postulacie historyzmu u Kołłątaja zob. H. Hinz, Filozofia Hugona Kołtataja. Zarys monografii, Warszawa 1973, s. 101-106.

${ }_{58}$ M. Janion, M. Żmigrodzka, dz. cyt., s. 27-28.

${ }^{59}$ X. HugonaKottatajakorespondencja listownazTadeuszem Czackim,t.4, wyd.F.Kojsiewicz, Kraków 1845, s. 1; por. też J. Polanowska, Historiografia sztuki polskiej w latach 1832-1863 na ziemiach centralnych i wschodnich dawnej Rzeczypospolitej: F.M. Sobieszczański, J.I. Kraszewski, E. Rastawiecki, A. Przezdziecki, Warszawa 1995, s. 45. 
Sztuka zaczęła więc być uznawana za element dziedzictwa po przodkach, co przecierało drogę dla idei architektury narodowej.

Tego typu wątki zapowiadały też przemianę, jaka nastapiła w trzeciej i czwartej dekadzie XIX w., gdy ogólnoeuropejski fenomen „odkrycia” architektury średniowiecznej dotarł $\mathrm{w}$ pełni na ziemie dawnej Rzeczypospolitej. Uznanie dla form gotyckich, choć poprzedzone już jego zadomowieniem się $\mathrm{w}$ obiektach mniejszego znaczenia (królewski łuk triumfalny w Warszawie w 1764 r., pawilony ogrodowe), pojawiło się $\mathrm{w}$ architekturze pałacowej od przełomu XVIII i XIX w.$^{60}$ Decydowała tu możliwość dość dowolnego, niesymetrycznego kształtowania bryły dużych obiektów. Inspiracje szły z Wielkiej Brytanii i to już od schyłku XVIII w. Wspomnijmy też o impulsie do odkrywania na nowo idei chrześcijaństwa we wspomnianej książce Chateaubrianda, a także o głoszonym na politechnice paryskiej przez architekta Jean-Nicolas-Louis Duranda pragmatyzmie w wyborze stylu architektonicznego dla budowli (odejście od prymatu wzorów architektury antycznej) ${ }^{61}$. To wszystko przyczyniło się do uświadomienia sobie wagi architektury średniowiecznej także $\mathrm{w}$ badanym regionie i sprawiło, że zasadne stało się pisanie, a potem też dbanie o zabytki gotyckie.

Towarzyszyło temu większe zainteresowanie średniowieczną historią w okresie „przesilenia” romantycznego. Historycy badający dzieje narodu mieli „wyjśćc z tegoż właśnie narodu, a proces ten można porównać, używając terminologii Mochnackiego, do „samopoznania się narodu w swoim jestestwie". Wspomniane na początku poszukiwania starożytnicze oraz powracanie do korzeni narodowych w literaturze romantycznej niosły ze sobą tendencję do uobecniania narodowej przeszłości $^{62}$ i wzbudzania nastroju patriotycznego uniesienia. Wątki melancholii i tęsknoty za dawna, wielką przeszłością były obecne od czasów późnego oświecenia, a ważnym nurtem romantycznego pisarstwa były opisy podróży po ziemiach dawnej Rzeczypospolitej oraz poematy, których scenerią były rubieże dawnego państwa. Największym rozrzewnieniem napawały tych twórców ruiny zamków rodowych oraz dawne kościoły katolickie, będące niemymi świadkami historii i źródłami wiedzy

${ }^{60} \mathrm{Na}$ temat losów gotyku na ziemiach polskich zob. T.S. Jaroszewski, O siedzibach neogotyckich w Polsce, Warszawa 1981.

${ }_{61}$ Pragmatyzm jako ważny rys myśli Duranda podkreślił Andrzej Rottermund; zob. tenże, Rola doktryny Jean-Nicolas-Louis Duranda w architekturze europejskiej 1 pot. XIX wieku, w: Myśl o sztuce. Materiaty Sesji zorganizowanej z okazji czterdziestolecia istnienia Stowarzyszenia Historyków Sztuki, Warszawa, listopad 1974, red. T. Hrankowska, Warszawa 1976, s. 143-150, tu s. 150.

${ }^{62}$ K. Poklewska, Galicja romantyczna 1816-1840, Warszawa 1976, s. 208. 
historycznej ${ }^{63}$. Do twórców łączących różnorodne zamiłowania związane z przeszłością należeli i wieszczowie narodowi, i pomniejsi twórcy. Wśród nich spotkać można Adama Mickiewicza, Kazimierza Brodzińskiego, Seweryna Goszczyńskiego, Antoniego Malczewskiego, Wincentego Pola czy Ignacego Kraszewskiego. Pamiątki narodowe kolekcjonowali wielcy arystokraci, co jednak ważne, literatom i poetom towarzyszyli domorośli „starożytnicy”, pochodzący także ze zubożałej szlachty lub z mieszczaństwa, a więc $\mathrm{z}$ warstw tracących od kilku dekad swoje znaczenie w społeczeństwie. Ich niezaspokojona ciekawość, autentyczna namiętność kolekcjonerska i ciężka praca pozwoliły nieraz zdobyć wysoka pozycję, zwykle nie majątkowa, a naukową (zgodnie z ówczesnymi standardami) i społeczna jako strażnicy pamięci o wielkich dziejach narodowych. Do takich piewców przeszłości należał np. kronikarz Krakowa Ambroży Grabowski, starożytnik Łukasz Gołębiowski, numizmatyk, sfragistyk i historyk architektury Kazimierz Stronczyński (o którym niżej), literat Kazimierz Władysław Wójcicki, architekt Bolesław Podczaszyński czy zbieracz pieśni ludowych Żegota Pauli. Byli historykami, geografami, etnografami, archeologami i historykami sztuki w jednej osobie, by użyć nazw nauk, które w niektórych przypadkach dopiero się miały wykształcićc ${ }^{64}$.

Wskazać należy na jeszcze jeden kontekst tych przemian mentalnych, gdyż uznanie dla pozostałości z wieków średnich rosło w niesprzyjających dla nich okolicznościach. Akcja modernizowania tkanki miejskiej w ośrodkach dawnej Rzeczypospolitej, niezależnie od tego, przez które władze dokonywana (Austriaków w Krakowie i Lwowie przełomu XVIII i XIX w., Prusaków w Poznaniu czy - krócej - Płocku w początku XIX w. bądź suwerenne władze Królestwa Polskiego w Warszawie, Kaliszu, Radomiu, Kielcach i Piotrkowie po 1815 r.), prowadziła do wyburzeń części dawnych murów i bram oraz ratuszy. Sprzeciw wobec tych posunięć najszybciej pojawił się w Krakowie, gdzie w latach 1796-1809 zburzono aż 15 dawnych kościołów ${ }^{65}$. Krytycy wyburzeń, jak np. senator krakowski Feliks Radwański, widzieli w dawnych

${ }^{63} \mathrm{O}$ tym motywie twórczości zob. S. Burkot, Polskie podróżopisarstwo romantyczne, Warszawa 1988.

${ }^{64} \mathrm{Na}$ temat starożytnictwa zob. A. Abramowicz, Dzieje zainteresowań starożytniczych w Polsce, cz. 2: Czasy stanisławowskie i ich pokłosie, Wrocław 1987; por. też: J. Kowalczyk, Starożytnicy warszawscy połowy XIX w. i ich rola w popularyzacji zabytków ojczystych, w: Edukacja historyczna społeczeństwa polskiego w XIX w. zbiór studiów, red. J. Maternicki, Warszawa 1981, s. 157-202.

${ }_{65}$ W. Ślesiński, Problemy konserwatorskie Krakowa w pierwszej połowie XIX wieku, „Ochrona Zabytków” 16, 1963, z. 1, s. 3-16, tu s. 4. 
basztach, bramach i murach przede wszystkim aspekt ich dawności oraz fakt, że ich powstanie łączyło się najczęściej z okresem największej potęgi dawnej Rzeczypospolitej ${ }^{66}$. Dopiero pod koniec omawianego okresu, wraz z unaukowieniem historii sztuki, pojawiły się argumenty wskazujące na gotyckość tych budowli, niemniej dyskurs związany z docenieniem tego stylu był obecny w debatach dotyczących porównania stylów architektonicznych.

Przejdźmy teraz do przemyśleń propagatorów gotyku z kręgów estetyków i architektów, gdyż ich myśl była również rodzajem ukontekstowienia wspomnianego już dyskursu wzniosłości. Przypomnijmy jeszcze raz stanowisko klasycystów. Piękno było jedna, niepodzielną wartościa, a jej źródeł upatrywać można było w „guście” starożytnych. Formy antyczne miały być logiczne i wynikające z zasad. Przeciwnie, w gotyku widziano dowolność, a nawet rodzaj chaosu. Jak pisał Józef Łęski o kościołach „gockich”: „uważamy w nich mieszkaninę barbarzyństwa, wyborności siły i znikomości; zamykamy się nad niezmierna praca ludzką i wysileniem się sztuki. Wzrusza się imaginacya nasza, pamiątki które te zabytki odnawiaią i wiele pomieszanych wyobrażeń dopełniaią im charakter poważny, uroczysty, iakiego ich przeznaczenie wyciaga a którego odiać im nie mogą ozdoby znikome i niezgrabne iakiemi sa obładowane" ${ }^{67}$. W tej wypowiedzi natrafiamy na kluczowe kwestie. Gotyk działał poprzez swą śmiałość, konstrukcję i skłaniająca do kontemplacji formę, a raził przeładowaniem i przypadkowościa detali. Tak konstrukcja, jak i wertykalna forma były cechami w pełni aprobowanymi przez estetyków takich jak Kremer i Libelt. Większym problemem było tu uznanie struktury budowli oraz dekoracji za przypadkowa, niewynikająca z jakichś jednolitych reguł, które widziano w sztuce antycznej. Jednak nawet i te kwestie stały się przedmiotem (nieśmiałej) obrony ze strony teoretyków. Wskazać tu można na teorię dotyczącą piękna estetycznego arabesek (widzianych tu jako rodzaj dekoracji średniowiecznych), które to piękno miało być dla Libelta jednym z dowodów autonomii sztuki i zasady, że nie naśladuje ona Natury ${ }^{68}$. W 1860 r. jeden z krytyków sztuki uznał, że „drobne czastki”, z jakich składa się architektura gotycka, tworzą harmonijną całość w bryle ${ }^{69}$. Z kolei Wincenty Pol zaproponował własne wyjaśnienie genezy tej dekoracji. Jego teoria

${ }^{66}$ Por. np. M. Borowiejska-Birkenmajerowa, Serce Polski: zabytki i świadomość narodowa, Kraków 1991.

67 J. Łęski, dz. cyt., s. 269.

${ }^{68}$ K. Libelt, dz. cyt., s. 338.

${ }^{69}$ Ostoja, Kilka słów o Architekturze Narodowej, „Kronika Wiadomości Krajowych i Zagranicznych", 5/17 I 1860, s. 3-4, tu s. 4. 
„filigranowego gotycyzmu”, przedstawiona w Objaśnieniach do znanego dzieła o Wicie Stwoszu, wywodziła zdobnictwo wielkich katedr z drobnej sztuki złotniczej relikwiarzy, kielichów, monstrancji, ampułek oraz sprzętów kościelnych. W ten sposób dekoracja stanowiła zastosowanie ornamentu z obiektów małej skali na obiekty dużej skali ${ }^{70}$.

Do wczesnych, dojrzałych propagatorów gotyku jako stylu, który można zastosować do nowych budowli (a więc w istocie neogotyku), należał działajacy m.in. w Warszawie architekt Adam Idźkowski. Dla autora neogotyckiej przebudowy katedry warszawskiej sztuki piękne musiały oczywiście „wznosić duszę do wyższego stanowiska” jako owoc rozwiniętych „sił moralnych”. Co ciekawe, w jego artykule dla „Biblioteki Warszawskiej” z 1845 r. ideał piękna ukazany został - w odróżnieniu od teorii klasycystycznej - jako zmienny. Jak autor to uzasadniał? Powiązał go z przemianami w nauce i myśli ludzkiej, łącząc $\mathrm{w}$ ten sposób sztukę z idea postępu i rozwoju nauki ${ }^{71}$, co antycypowało przemiany ideowe w kolejnych dekadach. Sztuka miała czerpać siły także z nauki. Jak pisał: „dziś postępująca sztuka, otrząsając się z przesądów i materializmu, posłuszna duchowi czasu, wprowadza do swych form ogólniejsze i godne swojej epoki myśli”72. Ów duch czasu był figura, która wprowadzała opisywaną przeze mnie kontekstualizację teorii estetycznych. Ta drogą poszli kolejni teoretycy gotyku, którzy analizowali formy architektoniczne w coraz większych szczegółach, starając się dociec, co właściwie wpływa na określanie danej budowli jako pięknej i tym samym odchodząc od niekwestionowanego wcześniej ideału antycznego.

Piewcy szeroko pojętych idei klasycystycznych bronili się, przekonując, jak warszawski architekt Julian Ankiewicz, że te same zasady piękności stosuja się do różnych typów architektonicznych ${ }^{73}$. W tym samym artykule jednak dał się sprowokować i podjał się drobiazgowej analizy form antycznych, dowodzac, że sa one zgodne z prawami statyki i co za tym idzie ekonomicznie racjonalne. Szczegółowa analiza form i wymiarów pomagała jednak budować linię argumentacji

${ }^{70}$ Dzieła Wincentego Pola wierszem i proza, t. 1: Poezje, Lwów 1875, s. 76; zob. U. Bęczkowska, Wincenty Pol a poczatki instytucjonalnej opieki nad zabytkami sztuki $w$ Polsce, w: Wincenty Pol (1807-1872) w stużbie nauki i narodu, red. K. Grodzińska, A. Kotarba, Kraków 2010, s. 90.

${ }^{71}$ A. Idźkowski, Stanowisko sztuk pięknych, „Biblioteka Warszawska” 1, 1845, s. $678-690$, tu s. 685 .

72 Tamże, s. 679.

${ }^{73} \mathrm{~J}$. Ankiewicz, O architekturze gotyckiej, „Biblioteka Warszawska” 4, 1849, s. 39-65. 
sprzyjająca pluralizmowi stylistycznemu. Tak było w wywodach warszawskiego krytyka architektury Karola Matuszewskiego publikowanych w czasopiśmie „Inżenieria i Budownictwo”, gdzie autor dokonał podziału budowli w zależności od tego, który z trzech wymiarów w nich przeważa. Wyodrębniając budowle wysokie (wzniosłe), szerokie (trwałe i mocne) i głębokie (budzące trwogę), mógł przyporządkować je do dominujacych w danej epoce tendencji. Architektura „induska” charakteryzowała się głębokościa, egipska szerokościa, a europejska wysokością (tu na pierwszym planie stał już gotyk). Oczywiście nie zapomniał o antyku, architektura grecka, nadal ideał piękna, oznaczała harmonię wszystkich tych wymiarów ${ }^{74}$. Co ważne, w ten sposób gotyk, choć o formach przesadnie wertykalnych, mógł mieć swoje należne miejsce $\mathrm{w}$ historii architektury.

W ten sposób przeszliśmy do następnego okresu, gdy klimat intelektualny został zdominowany w dużej mierze przez pozytywizm oraz nowe, bardziej trzeźwe podejście filozoficzne: empiryzm i materializm, a także wpływ nauk biologicznych. Nowym trendem było również ciagłe porównywanie Polski z Zachodem, tym razem bez zakładania a priori wyższości (choćby moralnej) tej pierwszej. Ta potrzeba badań empirycznych i komparatystyki wynikała ze wspomnianego tu już postulatu unaukowienia. Poznawanie narodowej przeszłości ulegało unaukowieniu jeszcze w czasach dominacji romantyzmu. Proces włączania dzieł sztuki do badań historycznych i łączenia w jednym warsztacie badawczym znajomości sztuki i historii został zbadany przez Jolantę Polanowska ${ }^{75}$. Autorka opisała powstanie pierwszych syntez dziejów sztuki polskiej pióra Maksymiliana Sobieszczańskiego, Józefa Kraszewskiego, Edwarda Rastawieckiego i Aleksandra Przezdzieckiego, zwracając uwagę na stopniowe unaukowienie tych prac oraz przejście od opisu żywotów artystów i dzieł sztuki po badania dziejów sztuki jako takiej (Kunstgeschichtsforschung) w trzech dekadach międzypowstaniowych. Na podkreślenie zasługuje tu prymat ośrodka warszawskiego i w mniejszym stopniu wileńskiego i krzemienieckiego. Mimo represji po powstaniu listopadowym i zamknięciu KWTPN, po dekadzie zamarcia życia intelektualnego, od lat czterdziestych pojawiły się ważne czasopisma, jak „Biblioteka Warszawska”, z której łamów już nieraz tu korzystałem. Jednym z celów tych wszystkich badań było m.in. ustalenie, czy dawna Polska „dorobiła się” własnej sztuki, już nie jako pamiątki po dawnych

${ }^{74} \mathrm{~K}$. Matuszewski, O estetycznem $i$ dziejowem znaczeniu ostrołukowej architektury, „Inżenieria i Budownictwo” 3, 1882, s. 21-22; 5, 1882, s. 35; 8, 1882, s. 71-73.

75 J. Polanowska, dz. cyt. 
wiekach, ale pewnej wartości obiektywnej w skali europejskiej, wartej wydzielenia jako element ogólnych dziejów sztuki ${ }^{76}$.

Badania historyczne, tym razem koncentrujące się głównie na architekturze, rozpoczęły się na dobre w ośrodku, który w pierwszej połowie XIX w. pozostawał w cieniu Warszawy: w Krakowie. Po ustanowieniu teoretycznie suwerennej Rzeczypospolitej Krakowskiej zawiązano w tym mieście Towarzystwo Naukowe przy Uniwersytecie Jagiellońskim, którego celem była badanie kultury polskiej ${ }^{77}$. Składało się ono przede wszystkim z uczonych, a nie amatorów ${ }^{78}$. Tamtejszy Oddział Sztuk i Archeologii (potem Oddział Archeologii i Sztuk Pięknych) nie zajmował się jednak miejskimi zabytkami aż do wielkiego pożaru miasta w 1850 r., który pokazał, jak słabo sa one zbadane. Towarzystwo objęło opieka i nadzorem badania archeologiczne (w szerszym znaczeniu), a osobami, które miały tu największe zasługi, był Karol Kremer, brat Józefa, autor Skazówki dołączonej do Instrukcji dla prowadzacych wykopaliska ${ }^{79}$, a także Wincenty Pol, wzywający do poszanowania dawnych zabytków (m.in. w ważnym odczycie z 1868 r. pt. O potrzebie zachowania pomników $z$ przeszłości ${ }^{80}$ ). Co istotne, pożar ten był okazja do naukowego zajęcia się architektura gotycka, gdyż to wspomniany Kremer oraz inny członek Towarzystwa Teofil Żebrawski byli autorami odbudowy obu spalonych w pożarze kościołów krakowskich, franciszkańskiego i dominikańskiego, a przy okazji tych działań - podobnie jak wspomniany Adam Idźkowski w Warszawie - uczyli się logiki konstrukcji gotyckich ${ }^{81}$. Architektura wieków średnich przestawała więc być wyłącznie obiektem miłości platonicznej, ale stawała się także przedmiotem zachwytu nad myśla konstrukcyjną dawnych budowniczych ${ }^{82}$. Świadectwem wejścia neogotyku na stałe do repertuaru form w ówczesnej architekturze, a nawet zachłystnięciem się nim w latach osiemdziesiątych

${ }^{76}$ Można przypomnieć, że naukowy postulat określenia, jaki był zewnętrzny wpływ na polską sztukę, postawił Wincenty Pol; por. U. Bęczkowska, dz. cyt., s. 76.

77 J. Dużyk, A. Treiderowa, Zagadnienia opieki nad zabytkami w działalności Towarzystwa Naukowego Krakowskiego, „Rocznik Biblioteki Polskiej Akademii Nauk w Krakowie" 3, 1957, s. 203.

78 D. Rederowa, Powstanie i ustrój Towarzystwa Naukowego Krakowskiego (1815-1872), „Kwartalnik Historii Nauki i Techniki” 14, 1969, z. 1, s. 53-74.

${ }^{79} \mathrm{O}$ nim zob. U. Bęczkowska, Karol Kremer i Krakowski Urzad Budownictwa w latach 1837-1860, Kraków 2010.

${ }^{80} \mathrm{Na}$ temat roli Pola zob. taż, Wincenty Pol..., s. 71-95.

${ }^{81}$ Taż, Karol Kremer...

${ }^{82}$ Niemała była tu też rola francuskiego wpływu Eugène’a Emmanuela Viollet-le-Duca i jego wielkiego Dictionnaire raisonné du mobilier français de l'époque carolingienne à la Renaissance. 
był artykuł Stanisława Chołoniewskiego opublikowany na łamach lwowskiego „Czasopisma Technicznego”, gdzie autor podkreślał równoprawność stylów, a także stosowność gotyku jako podstawy stylu narodowego $^{83}$. W sumie więc gotyk jako istotny w historii styl architektoniczny powoli przebijał się do świadomości elity ${ }^{84}$, by ostatecznie zawładnąc umysłami architektów i archeologów. Duże znaczenie miało włączenie się do dyskusji Władysława Łuszczkiewicza ${ }^{85}$, krakowskiego malarza i historyka sztuki, który podją badania nad budownictwem średniowiecznym, szczególnie małopolskim.

\section{Wojna kulturowa?}

Te badania naukowe przeprowadzane były w tym samym czasie, kiedy przewartościowaniu uległo podejście do dziedzictwa przodków. Świadomość, że Rzeczpospolita była krajem peryferyjnym, w którym sztuka rozwijała się z oczywistych względów słabiej niż np. we Francji, pojawiła się wyraźniej właśnie w czasach pozytywizmu. Do dyskursu związanego ze sztuką wątek ten wprowadzony został już nieco wcześniej. Przypomnijmy tu artykuł malarza krakowskiego i członka Towarzystwa Naukowego Wojciecha K. Stattlera z połowy wieku, z okresu tworzenia syntez dziejów sztuki Sobieszczańskiego, Rastawieckiego i Przezdzieckiego. W swych pesymistycznych przemyśleniach na temat niskiego poziomu obycia ze sztuką wśród wszystkich warstw społecznych Stattler zauważał, że celem znajomości sztuki było posiadanie „własnego typu narodowego", który miał się z jednej strony objawiać w świadomości artystycznej szlachty i mieszczaństwa oraz we własnym języku artystycznym $^{86}$. Ludwik Buszard, krytyk pochodzenia francuskiego, który $\mathrm{w}$ swej recenzji z jednej z wystaw malarstwa w 1860 r. popierał sztukę narodowa, chwaląc „polskość” obrazów, w których widział „dźwięk

${ }^{83}$ S. Chołoniewski, Poglad historyczny na architekture średniowieczna a $w$ szczególności gotycka, zabytki jej u nas $i$ nowe budowle w tym stylu, „Czasopismo Techniczne" 1, 1885, s. 1-4.

${ }^{84}$ J. Frycz, Neogotyk i restauracja zabytków w Polsce, w: Sztuka 2 połowy XIX wieku. Materiaty Sesji Stowarzyszenia Historyków Sztuki Łódż, listopad 1971, red. T. Hrankowska, Warszawa 1973, s. 173-182.

${ }^{85} \mathrm{Na}$ przykład w książce: W. Łuszczkiewicz, $O$ znaczeniu $w$ dzisiejszych czasach budownictwa średniowiecznego: kilka uwag z dziedziny sztuki, Kraków 1869 oraz w artykułach publikowanych w czasopismach technicznych.

${ }^{86}$ W.K. Stattler, Myśli względem podniesienia sztuk pięknych w kraju, „Rocznik Towarzystwa Naukowego Krakowskiego” 4 (19), 1849, s. 125-144, tu s. 139. 
ojczystej mowy”, „nasze pola, chaty, lasy, nasze niebo i wiar[ę] nasz[a]”87, jednocześnie zdawał sobie sprawę, że polska kultura artystyczna jest dopiero na etapie tworzenia, że to dopiero „grunt dziewiczy, po którego powierzchni przesuwa się dzisiejsza przemysłowa cywilizacya nie sięgając do jego głębin"88. Był to ważny wniosek, gdyż kultura była tu pojmowana jako rodzaj kapitału społecznego avant la lettre. Świadomość potencjalnej słabości sztuki polskiej widać też w pismach Józefa Łepkowskiego, dla którego co prawda konserwatorstwo była to „trzeźwa nauka co tutaj przyszła odróżnić ważne od błachego [sic!], pamiątkę od zabytku sztuki, antykwarstwo od badania i studyum ścisłego"89, ale który jednocześnie $\mathrm{w}$ tym samym piśmie zdradzał odmienną motywację prowadzonych badań przez Polaków i ich sasiadów, a przy tym, moim zdaniem, źródło potencjalnego braku pełnego obiektywizmu u polskich badaczy: „Im [towarzystwom niemieckim i francuskim - A.Ł.] wolno rozdzielać siły na drobiazgowe studya; kiedy nam głównie i przedewszystkiem chodzi o gromadzenie $\mathrm{w}$ narodowe ognisko i tych iskierek życia co się w ojczystych grobach ukryły. Sassiadom wolno analizować przeszłość czyniąc na niej niby na trupie naukowe experymenta; nam zaś tylko ja ożywiać i wskrzeszać potrzeba"90. Naukowość konserwacji zabytków szła więc $\mathrm{w}$ parze $\mathrm{z}$ prowadzonym dyskursem narodowym, który wpływał na podejmowane decyzje i sposób, w jaki postrzegano zabytki historyczne. Aby zrozumieć ten aspekt, trzeba przypomnieć kontekst europejski, gdzie instytucjonalna ochrona zabytków była przedsięwzięciem politycznym, podejmowanym wprost przez władze państwowe w tzw. nation-states. Urzędy były scentralizowane, a stojący na ich czele architekt lub archeolog gwarantował realizację jednolitych wytycznych ${ }^{91}$.

${ }^{87}$ L. Buszar[d], O stosunku sztuki do naszego społeczeństwa, „Biblioteka Warszawska” 3, 1860, s. 129-152, tu s. 141.

88 Tamże, s. 150.

89 J. Łepkowski, O poszanowaniu zabytków ojczystej przeszłości, Kraków 1862, s. 2.

90 Tamże, s. 10.

${ }^{91}$ Przykładem mogą być Prusy, gdzie akcją ochrony zabytków kierował architekt Karl Friedrich Schinkel, a celem było m.in. ujednolicenie poszczególnych regionów obszernego państwa; zob. pierwszy rozdział w: M.S. Falser, Zwischen Identität und Authentizität. Zur politischen Geschichte der Denkmalpflege in Deutschland, Dresden 2008. W Austrii w ramach modernizacji państwa w okresie neoabsolutyzmu połowy XIX w. powołano w latach 1850-1853 instytucję majacca scentralizować w Wiedniu działania w celu inwentaryzacji i opieki nad zabytkami; por. W. Frodl, Idee und Verwirklichung: das Werden der staatlichen Denkmalpflege in Österreich, Wien 1988. Wraz z decentralizacją austriackiej części monarchii po 1867 r. urzędy krajowe zyskały spora autonomię; por. pierwszy rozdział w: M. Rampley, Vienna School of Art History. Empire and the Politics of Scholarship, 1847-1918, University Park 2015. Takim centralnym konserwatorem we Francji był z kolei Prosper Mérimée. 
W ciagu XIX w. kultura, która zgodnie z powszechnym przekonaniem wyrażała ideały narodu, coraz bardziej stanowiła jedno z pól rywalizacji między rozwijajaccymi się państwami narodowymi, a Miles Glendinning, badacz zagadnienia konserwacji, pisał wręcz o dziewiętnastowiecznym „imperializmie kulturowym”92. W tym świetle można spojrzeć na wielka wrzawę, jaka nastapiła po prowokacyjnym wysunięciu przez krytyka literackiego i znawcę sztuki Juliana Klaczkę w 1857 r. tezy, że Polska nie ma własnej sztuki ${ }^{93}$. Nie dziwne też, że zaniepokojeni tą debata naukowcy z Towarzystwa Naukowego Krakowskiego ogłosili w 1858 r. konkurs (wznowiony w 1861 r.), którego zadaniem było zebranie głosów mających: „Wykazać na zabytkach naszych, a przez porównanie ich z obcymi wyjaśnić: Czyli są i jakie cechy budownictwa i rzeźby właściwe Polsce? Zarazem oznaczyć właściwości owe, jeźli jakich, szczególniej architektura, pod niebem naszym nabyła"94. Konkurs nie przyniósł oczekiwanych rezultatów, ale pokazuje on, w jakim kierunku rozwijało się również myślenie o zabytkach w tym czasie.

Narzędziem do „wykuwania” tego typu oręża w dyskusjach na niwie europejskiej była systematyczna inwentaryzacja zabytków, której temat powracał w rozważaniach Towarzystwa w kolejnych latach. Ale tu pionierem nie tylko na badanych ziemiach, ale i w całym regionie był ośrodek warszawski, skąd dwukrotnie wyszła idea stworzenia w miare kompletnego katalogu zabytków. Misja tego typu została ostatecznie powierzona przez Radę Administracyjną wspomnianemu już Kazimierzowi Stronczyńskiemu w $1844 \mathrm{r}^{95} \mathrm{~W}$ ciagu dziewięciu lat zinwentaryzował on zabytki we wszystkich guberniach Królestwa Polskiego, choć do ostatecznego druku powstałych wówczas pięciu tomów nie doszło wskutek sytuacji politycznej po 1863 r. Uwaga Stronczyńskiego była skupiona właśnie na interesujacych nas zabytkach średniowiecznych, choć z przyczyn praktycznych skupiono się tylko na zabytkach murowanych. Za ciosem poszli też miłośnicy zabytków w Krakowie.

${ }_{92}$ Zob. rozdział Revolutions and National Heritages w: M. Glendinning, The Conservation Movement. A History of Architectural Preservation. Antiquity to Modernity, London 2013. Na patriotyzm jako element kształtujący spojrzenie na architekturę historyczna wśród Polaków zwracał uwagę T. Rudkowski, Poglady na zabytek $w$ Polsce lat sześćdziesiatych XIX wieku, w: Myśl o sztuce..., s. 127.

${ }_{93}$ Dyskusja ta została już wyczerpująco przedstawiona w: Z dziejów polskiej krytyki i teorii sztuki, t. 2: Spór o rację bytu polskiej sztuki narodowej (1857-1891), oprac. I. Jakimowicz, Warszawa 1961, s. 6-184.

${ }_{94}$ Archiwum PAN, Oddz. w Krakowie, sygn. TNK-73, k. 8, cyt. za: J. Dużyk, A. Treiderowa, dz. cyt., s. 216.

${ }_{95}$ H. Delimat, Kazimierz Stronczyński. Życie i działalność (1809-1896), „Studia i Materiały z Dziejów Nauki Polskiej”, Seria E, z. 5, 1973, s. 281-327, tu s. 306. 
W 1847 r. miała miejsce pierwsza z serii podróży inwentaryzacyjnych Józefa Łepkowskiego po Galicji (później badania objęły także wybrane tereny zaboru rosyjskiego i pruskiego ${ }^{96}$.

Przejdźmy do ostatniego wątku, rosnącego poczucia pesymizmu kulturowego wśród polskich elit. Wraz z pozytywizmem, jak wspomniałem, upowszechniano także wyniki rozwijajacych się nauk przyrodniczych, w tym także dzieło Karola Darwina i jego propagatorów, takich jak Ernst Haeckel. Darwinizm przeniesiony na grunt społeczny z łatwością mógł prowadzić do wizji wojny między narodami o przetrwanie, co mogło dotyczyć także dziedziny wytwórczości. W tym duchu pisano jeszcze u progu popularności darwinizmu. Przywołany wyżej Buszard uważał, zgodnie właśnie z owym duchem epoki, że te cywilizacje zwyciężaja, które zapewniaja zwycięstwo swoich idei. Sztuce przyznawał olbrzymią rolę, miała nie tylko rozwijać ducha narodowego, ale wręcz „tworzyć nowy świat”97. Łepkowski w swej książce z 1862 r. stwierdzał, że to ludy „zwycięskie” zostawiają źródła dla archeologów ${ }^{98}$, a nieco później Adam Chmielowski, referując książkę Charles'a Blanca o gramatyce sztuki z 1870 r., pisał, że „narody przeczuły, że ich sława będzie mierzona dziełami poety i architekta, rzeźbiarza i malarza, bo nie ma narodu, któryby [sic!] nie szanował artystów, jako przyszłych świadków swojej wielkości" ${ }^{9}$. Powiązanie sztuki i narodu przebija się też przez teorie architektów-praktyków tej miary co Julian Zachariewicz, profesor Instytutu Politechnicznego we Lwowie, uznawany za ojca lwowskiej szkoły architektury. W odczycie z $1877 \mathrm{r}$. uznał on, że style potrafią być wyrazem woli wspólnej całych narodów, a sztuka przejawem ducha narodu. Wpisując się w długi dyskurs kulturalny narodu bez własnego państwa, dodawał, że klęski polityczne nie są siła, która mogła zniszczyć owego ducha, a narody pielęgnujące go nigdy nie gina ${ }^{100}$. Te wszystkie przemyślenia wskazują na coraz większą rolę, jaką przyznawano w stuleciu XIX (wieku sztuki i muzeów) artystom, ale też spuściźnie przodków.

Gdy jednak zaczęto łączyć wyniki badań nad ową spuścizną przodków z wnioskami płynącymi z idei (szeroko pojętego) darwinizmu społecznego, rezultatem bywał właśnie pesymizm, co ilustrują moim zdaniem poniższe cytaty. Studia nad historią rodzimej architektury, w których

${ }_{96}$ B. Antoniewicz-Goraj, Między teoriq a praktyka. Aktywność Józefa Eepkowskiego $w$ dziedzinie konserwacji zabytków, „Wiadomości Konserwatorskie” 17, 2005, s. 14.

${ }^{97}$ L. Buszar[d], dz. cyt., s. 133.

98 J. Łepkowski, dz. cyt., s. 6.

99 A. Chmielowski, $O$ istocie sztuki, „Ateneum” 2, 1876, z. 5, s. 428-432, tu s. 428.

100 J. Zachariewicz, Odczyt o architekturze. Wygłoszony 19 marca 1877, Lwów 1877, s. 29. 
upatrywano nadzieję na stworzenie podstaw do odkrycia polskiego wkładu w historię, polskiego „rysu” w architekturze dawnych wieków, niekoniecznie dawały asumpt do samozadowolenia. Wybór gotyku jako tego stylu, z którym wiązano największe nadzieje, był oczywisty, gdyż renesans długo uważano za styl obcy. Architekt Filip Pokutyński uznał gotyk za ważny styl w historii Polski, który mógłby się rozwinąć w kierunku bardziej narodowym, gdyby ,jej wątku nie przerwała epoka renesansu narzuconego światu północnemu przez monarchów i możnych panów"101. Według warszawskiego krytyka architektury (ale też niedoszłego malarza) i obrońcy idei stylu „wiślano-bałtyckiego” Karola Matuszewskiego ${ }^{102}$ różne style rozwijały się jak organizmy. Jednak styl gotycki, który zaczął nabierać polskich cech, został zmarginalizowany przez architekturę renesansowa, implantowaną tu przez dwór i włoskich budowniczych, zanim osiagną doskonałośćc ${ }^{103}$. Inny ważny styl, klasycyzm, również nabierał polskich cech w momencie, gdy upadło państwo, a tym samym zniknęły warunki do jego rozwoju. Konsekwencją tego, według autora, był dziewiętnastowieczny chaos w polskiej architekturze. Jak konkludował: „Architektom naszym nie dają one [tzn. słabe tradycje architektury miejscowej - A.Ł.] wymaganej podstawy: nie znajdują oni w nich żadnych prawie punktów oparcia. Wypadłoby im chyba zawrócić daleko wstecz, pochwytać umiejętnie rozpierzchłe i powiązać porwane od wieków watłe pasma budowlanych tradycyi i dopiero snuć je dalej świadomie, z uwzględnieniem nowych życia warunków"104. Dla Matuszewskiego rozwiązaniem był nowy styl, bazujaccy na gotyku. Ideę tę skrytykował Franciszek Ksawery Martynowski w swej książce z 1882 r. Przedstawił tam jeszcze smutniejsze konstatacje. Twierdził, że naród polski spełniał się raczej w obronie granic niż $\mathrm{w}$ tworzeniu kultury (motyw znany też z pism innych publicystów), style architektoniczne były przyjmowane dla ich nowości, a nie potrzeb „narodu”. Doszedł wręcz do wniosku, że „różne kierunki linii artystycznych przesuwają się przez ziemie nasze, przeciagają niby ptaki wędrowne"105. To zaś miało stanowić kontrast dla dobrze rozwiniętej sztuki na Zachodzie, dlatego artyści zachodni mogli, zdaniem Martynowskiego, „teraz odpoczacé, podczas gdy polscy powinni brać się do dzieła, i to od podstaw. Wtórował mu, jeśli chodzi o poziom pesymizmu, krakowski

101 F. Pokutyński, dz. cyt., s. 258.

102 A. Przymusiała, Matuszewski Karol, w: PSB, t. 20, 1975, s. 234-236.

${ }^{103} \mathrm{~K}$. Matuszewski, O architekturze u obcych $i$ u nas. Uwagi ze stanowiska estetycznego, „Biblioteka Warszawska” 3, 1881, s. 75-93, 231-245, 382-405, tu s. 80-81, 231.

104 Tamże, s. 387.

105 F.K. Martynowski, Na przełomie sztuki polskiej, Warszawa 1882, s. 35. 
architekt Władysław Ekielski, tym razem ujmując dzieje architektury w sposób bardziej ogólny. Analizując ówczesną renowację Sukiennic, pisał, że zbyt długie przerwy między poszczególnymi okresami popularności poszczególnych stylów sprawiły, że nie przyjmowały się one w pełni. Nie były wypracowywane, ale „importowane”, stąd nie było w polskiej architekturze ,żywej tradycji” ${ }^{106}$.

Moim zdaniem prezentowane powyżej wnioski nie były zabiegiem retorycznym mającym wzmocnić argumenty za poszukiwaniem stylu narodowego lub przeciw niemu, ale objawem pewnego „pesymizmu kulturowego" doby lat siedemdziesiąych i osiemdziesiątych. Ku tej tezie skłania też sytuacja, w jakiej się znalazły ziemie dawnej Rzeczypospolitej. Po 1864 r. okresowo wyczerpał się potencjał ośrodka warszawskiego (wcześniej też wileńskiego) jako przodującego w dyskursie i badaniu sztuki, m.in. z powodu dużych ograniczeń w zakresie środków wypowiedzi, cenzury i represji popowstaniowych. „Wspólnota komunikacji” w zaborze pruskim/niemieckim została też mocno ograniczona, nie tylko przez represje i likwidację instytucji polskich, ale i zdominowanie dyskursu naukowo-teoretycznego przez Prusaków. Jednocześnie archeologia, rozumiana dotąd w bardzo szerokim sensie, straciła impet, a liczba publikacji spadła. Jedynie ośrodki galicyjskie mogły się swobodnie rozwijać. Również idea, jaka miała przynieść nadzieję na stawienie oporu zaborcom na polu kultury, czyli styl „wiślano-bałtycki”, czekał dopiero na swój triumf w czasie konkursu na budynek praskiego kościoła św. Floriana.

\section{Wnioski}

Na zakończenie wypada jeszcze raz podkreślić ewolucję, jaką przeszło myślenie o dziedzictwie średniowiecznej architektury: od obojętności, przez spory o jej wagę, po kult gotyku i nadzieje wiązane z nim na przyszłość. Proces ten zachodził w kontekście rozwijania się państw narodowych i imperiów Europy Środkowej, gdy zadanie badania i opieki nad pamiątkami architektury zostały przejęte przez państwo i jego agendy. Ideałem dla państw Europy Środkowej stało się Kulturstaat, które w teorii oznaczało cywilizowanie się organizmów politycznych, a w praktyce dawało asumpt do powstania nowego wymiaru rywalizacji narodowych.

Jak wspominałem, wątkiem przewijającym się w pismach o zabytkach dawnej historii było napięcie między naukowością a amatorską

${ }^{106}$ W. Ekielski, Uwagi nad spótczesna architekturq $z$ powodu wystawy sztuki polskiej $w$ Sukiennicach, „Czasopismo Techniczne” 7, 1888, s. 52-56. 
pasja, które można uznać za symptom dwóch postaw: wczesnopozytywistycznej i romantycznej, ale które występowało w istocie od początku XIX w. np. w tekstach Adama Idźkowskiego ${ }^{107}$. O naukowość dopominał się Józef Łepkowski we wstępie do swego Utamka z podróży archeologicznej z 1849 r. Poddał tam krytyce praktyki romantycznego opisywania zabytków, ale zanim przystapił do przedstawienia opisu okolic, które zbadał wraz z Józefem Jerzmanowskim, opisu - przyznajmy - suchego i „naukowego" - tak oto umotywował fakt, że odwiedzanymi miejscami były głównie kościoły katolickie: „Kościół [...] umie opowiedzieć przeszłość. Koło jego to chrzcielnicy przechodził każdy mąż na drogę, która miał postępować, w nim w obrazach i pamiątkach zostawiał ślady swych czynów; sklepienie wreszcie tejże świątyni odbijało o swe łuki śmiertelne requiem, a kościelny grób przyjmował zwłoki dziedzica"108. Zauważalne tu napięcie wynikało z pewnej sprzeczności. Z jednej strony od kontekstu zaborów i potrzeby chronienia narodu przed kulturalnym unicestwieniem nie można było uciec, nawet późniejsza naukowa historia sztuki nosiła narodowo-patriotyczne piętno ${ }^{109}$. Z drugiej strony wyznaniem wiary pokolenia badaczy działajacego w drugiej połowie XIX w. była naukowość, pojmowana w duchu pozytywizmu, jako odarte z emocji analizowanie zebranego materiału, w tym wypadku dzieł dawnej architektury. Jak można zauważyć, ta wymuszona beznamiętność stała w sprzeczności z korzeniami całej dziedziny, czyli romantycznymi zainteresowaniami starożytniczymi, motywowanymi często tęsknotą za utraconą Rzeczpospolita. Praca badaczy sztuki zwiąanych z narodem pod zaborami może być moim zdaniem porównana do operacji ratującej życie, wykonywanej przez profesjonalnego lekarza na bliskim członku rodziny. Jednak oddanie inicjatywy naukowej w zakresie dziedzictwa Rzeczypospolitej w XIX w. w ręce obcokrajowców było sprzeczne z instynktem samozachowawczym i - jak można było się przekonać na podstawie np. badań zabytków prowadzonych przez Niemców w Poznańskiem, którzy chcieli w pierwszej kolejności wykazać niemieckość ziem tego zaboru - groziło marginalizacja tego dziedzictwa ${ }^{110}$. Dlatego jego analizą musieli zajmować się Polacy, którzy długo, dłużej niż

${ }_{107}$ A. Idźkowski, dz. cyt., s. 678 nn.

108 Utamek z podróży archeologicznej po Galicyi odbytej w r. 1849 przez Józefa Łepkowskiego i Józefa Jerzmanowskiego, „Biblioteka Warszawska” 3, 1850, s. 193-224, 416-454, tu s. 194.

109 M. Kunińska, Historia sztuki Mariana Sokołowskiego, Kraków 2014, s. 103.

110 M. Kutzner, Kult budowli średniowiecznych w Wielkim Księstwie Poznańskim, „Acta Universitatis Nicolai Copernici. Nauki Humanistyczno-Społeczne. Zabytkoznawstwo i Konserwatorstwo" 17, 1991, s. 161-188. 
przedstawiciele nauki na Zachodzie, byli sami uwikłani w przedstawiony przeze mnie świat wyobrażeń romantycznych, ale którzy jednocześnie współtworzyli międzynarodowy dyskurs naukowy oraz naukową sieć powiązań i odniesień.

Gotyk stał się stopniowo uznanym stylem budowlanym, ale też co tutaj istotne - kluczowym elementem polskiego dziedzictwa dla przywoływanych przeze mnie publicystów, a dla niektórych wręcz narodowym stylem polskim. Kult zabytków średniowiecznych prowadził w Krakowie do takich kontrowersyjnych pomysłów jak projekt nadbudowy gotyckimi szczytami ołtarza mariackiego (Władysław Łuszczkiewicz) czy wyburzenia renesansowych szczytów na Sukiennicach (Józef Łepkowski) ${ }^{111}$, co było przy okazji jednym z symptomów ówczesnych sporów o tzw. puryfikację zabytków. Ta wiara w gotyk przetrwała do końca zaborów, prowadząc jednak w końcu do przesytu, który spowodował, że w następnych dekadach neogotyk znikną niemal z architektury sakralnej, np. w zaborze rosyjskim ${ }^{112}$.

Prezentowane tu wątki debat, które można nazwać - być może nieco na wyrost - „wojną kulturowa”, świadczyły o szerszych trendach w Europie. Kosmopolityczna idea jednolitego postępu i rozwoju, nawiązująca do oświecenia, została zakwestionowana w czasie przełomu romantycznego. Następujący po dekadach triumfu romantyzmu okres dominacji wzoru beznamiętnej postawy naukowej był w sumie jednak niedługi, po czym powrócono do uwypuklania tego, co narody dzieli, a nie łączy. Pesymizm, który udzielał się niektórym przedstawicielom elity intelektualnej w ośrodkach dawnej Rzeczypospolitej, był przedsmakiem ogólnoeuropejskiego sentymentalizmu końca wieku, wynikającego także z rzekomej niemożności porozumienia się przedstawicieli różnych narodów. Przypomnijmy na koniec myślicieli, którzy pisali o odrębności cywilizacyjnej narodów, takich jak Arnold Toynbee czy Nikołaj Danilewski, ten ostatni również explicite wskazujący wagę różnic w sztuce dla siły poszczególnych narodów ${ }^{113}$. Pesymizm związany z narastającą rywalizacją między narodami (ergo także państwami narodowymi) miał różnorodne uwarunkowania, ale też cechy podobne do przedstawionego przeze mnie nieco wcześniejszego pesymizmu wśród polskiej elity.

111 T. Rudkowski, dz. cyt., s. 126.

${ }_{112}$ K. Stefański, dz. cyt.

113 T. Stefaniuk, Danilewski. Panslawizm i wielość cywilizacji, Lublin 2006, s. 108. 


\section{Bibliografia}

Abramowicz A., Dzieje zainteresowań starożytniczych w Polsce, cz. 1: Od średniowiecza po czasy saskie $i$ świt oświecenia, Wrocław 1983.

Abramowicz A., Dzieje zainteresowań starożytniczych w Polsce, cz. 2: Czasy stanisławowskie $i$ ich pokłosie, Wrocław 1987.

Antoniewicz-Goraj B., Między teoria a praktyka. Aktywność Józefa Łepkowskiego $w$ dziedzinie konserwacji zabytków, „Wiadomości Konserwatorskie” 17, 2005, s. 14-24.

Assmann J., Pamięć kulturowa: pismo, zapamiętywanie i polityczna tożsamość w cywilizacjach starożytnych, tłum. A. Kryczyńska-Pham, wstęp i red. R. Traba, Warszawa 2008.

Berlin I., Pod prad. Eseje z historii idei, red. H. Hardy, tłum. T. Bieroń, Poznań 2002.

Berlin I., Pokrzywione drzewo człowieczeństwa, red. H. Hardy, tłum. M. Pietrzak-Merta, M. Tański, Warszawa 2004.

Bęczkowska U., Karol Kremer i Krakowski Urzad Budownictwa w latach 1837-1860, Kraków 2010.

Borowiejska-Birkenmajerowa M., Serce Polski: zabytki i świadomość narodowa, Kraków 1991.

Cassirer E., Filozofia Oświecenia, tłum. T. Zatorski, Warszawa 2010.

Clark K., The Gothic Revival. An Essay on the History of Taste, London 1962.

Dopart B., Kultura polskiego romantyzmu: dynamika i pluralizm, w: Środowiska kulturotwórcze czasów oświecenia i romantyzmu, red. B. Dopart, Kraków 2013.

Dużyk J., Treiderowa A., Zagadnienia opieki nad zabytkami w działalności Towarzystwa Naukowego Krakowskiego, „Rocznik Biblioteki Polskiej Akademii Nauk w Krakowie” 3, 1957, s. 201-280.

Falser M.S., Zwischen Identität und Authentizität. Zur politischen Geschichte der Denkmalpflege in Deutschland, Dresden 2008.

Frodl W., Idee und Verwirklichung. Das Werden der staatlichen Denkmalpflege in Österreich, Wien 1988.

Frycz J., Neogotyk i restauracja zabytków w Polsce, w: Sztuka 2 połowy XIX wieku. Materiaty Sesji Stowarzyszenia Historyków Sztuki Łódź, listopad 1971, red. T. Hrankowska, Warszawa 1973, s. 173-182.

Glendinning M., The Conservation Movement. A History of Architectural Preservation. Antiquity to Modernity, London 2013.

Grzeliński A., Angielski spór o istote piękna. Koncepcje estetyczne Shaftesbury'ego i Burke'a, Torun 2001.

Janion M., Żmigrodzka M., Romantyzm i historia, Warszawa 1978.

Jaroszewski T.S., O siedzibach neogotyckich w Polsce, Warszawa 1981.

Kuderowicz Z., Filozofia nowożytnej Europy, Warszawa 1989.

Kunińska M., Historia sztuki Mariana Sokołowskiego, Kraków 2014.

Manufacturing Middle Ages. Entangled History of Medievalism in Nineteenth-Century Europe, red. P.J. Geary, G. Klaniczay, Leiden-Boston 2013. 
Pieróg S., Maurycy Mochnacki. Studium romantycznej świadomości, Warszawa 1982.

Poklewska K., Galicja romantyczna 1816-1840, Warszawa 1976.

Polanowska J., Historiografia sztuki polskiej $w$ latach 1832-1863 na ziemiach centralnych $i$ wschodnich dawnej Rzeczypospolitej: F.M. Sobieszczański, J.I. Kraszewski, E. Rastawiecki, A. Przezdziecki, Warszawa 1995.

Robson-Scott W.D., The Literary Background of the Gothic Revival in Germany. A Chapter in the History of Taste, Oxford 1965.

Rudkowski T., Poglady na zabytek $w$ Polsce lat sześćdziesiatych XIX wieku, w: Myśl o sztuce. Materiaty Sesji zorganizowanej z okazji czterdziestolecia istnienia Stowarzyszenia Historyków Sztuki, Warszawa, listopad 1974, red. T. Hrankowska, Warszawa 1976, s. 119-133.

Smith A.D., Etniczne źródła narodów, tłum. M. Głowacka-Grajper, Kraków 2009.

Walicki A., Filozofia polskiego romantyzmu, Kraków 2009.

Zieliński A., Poczatek wieku. Przemiany kultury narodowej w latach 1807-1831, Łódź 1973.

Aleksander Łupienko

Medieval monuments in a modern country. On the history of the Polish nineteenth-century discourse on architecture

(Summary)

The paper discusses changes taking place in the Polish aesthetical discourse in the period of partitions, from the early nineteenth century until the 1880s. The aim of the article is to show the evolution of aesthetical views on works of architecture and the theory of styles based on the example of the changing attitude towards Gothic architecture. The sources used in the analysis were penned by writers, aestheticians, architects, and other members of the intelligentsia who developed their theories and shared their views in journals and books published in Polish in the towns of the former Polish-Lithuanian Commonwealth (mainly in Warsaw, Kraków, Poznań, and Lviv), all of which dealt with old architecture and its importance for the present day. The analysis of the transforming opinions shows that the authors were looking for local specificity and native themes in Gothic architecture in order to subsequently - following the emergence of nationalist trends in Europe and the process of discourse creators becoming "entrenched" in their national "fortresses" - seek a deeper justification for the existence of the Polish nation in the history of architecture, despite the lack of Polish statehood. However, before Gothic started to be embraced as the national style and a potential basis for native art, critics of architecture started to notice the lack of continuity of its development in Poland, due to which they became overwhelmed with deep cultural pessimism, later overcome with the idea of Vistula-Baltic Gothic. 
Aleksander Lupienko (ur. 1980) - dr, historyk zatrudniony w Instytucie Historii im. Tadeusza Manteuffla Polskiej Akademii Nauk, w Zakładzie Historii Idei i Dziejów Inteligencji w XIX-XX wieku. Zajmuje się kulturową historia przestrzeni miejskiej Europy Środkowej i Środkowo-Wschodniej w „długim” stuleciu XIX (do 1914). Autor książek Przestrzeń publiczna Warszawy w pierwszej połowie XIX wieku, Warszawa 2012 (także w tłumaczeniu angielskim: Order in the Streets. The Political History of Warsaw's Public Space in the First Half of the $19^{\text {th }}$ Century, Frankfurt am Main 2020) oraz Kamienice czynszowe Warszawy 1864-1914, Warszawa 2015, za którą dostał Nagrodę KLIO oraz wyróżnienie w Varsaviana Konkursie im. Hanny Szwankowskiej. Publikuje w czasopismach i tomach w kraju i zagranica. Organizator cyklu konferencyjnego „Architektura w mieście, architektura dla miasta” (od 2016).

Aleksander Lupienko (b. 1980) - dr, historian working at the Tadeusz Manteuffel Institute of History, Polish Academy of Sciences, in the Department of the History of Ideas and the History of the Intelligentsia in the Nineteenth and Twentieth Centuries. He deals with the cultural history of urban spaces in Central and Central-Eastern Europe in the "long" nineteenth century (until 1914). He is the author of the books Przestrzen publiczna Warszawy w pierwszej połowie XIX wieku, Warsaw, 2012 (also published in English translation: Order in the Streets. The Political History of Warsaw's Public Space in the First Half of the $19^{\text {th }}$ Century, Frankfurt am Main 2020) and Kamienice czynszowe Warszawy 1864-1914, Warsaw, 2015, for which he received the KLIO Prize and an honorable mention in the Hanna Szwankowska "Varsaviana" Contest. He publishes articles in academic journals and volumes in Poland and abroad. He is the organizer of the Architektura $w$ mieście, architektura dla miasta conference cycle (since 2016).

E-mail: ollup@wp.pl. 